\title{
Psychosocial research and action with survivors of political violence in Latin America: methodological considerations and implications for practice
}

\author{
Maitane Arnoso Martínez \& Francisco José Eiroá-Orosa
}

Research with survivors of political violence in Latin America have shown that any analysis of the consequences of war or political repression should take into account the social and political realities in which the survivors are immersed. It has also shown that research must go hand in hand with action, intervention and psychosocial support for communities that confront violence. In this article, the authors review some of the basic principles that should guide research and action within the context of war or other political violence. We discuss the roles that the researcher needs to adopt in order to successfully develop work that will be of use to the social and scientific community. In addition, we describe some of the methodological implications of psychosocial research and the importance of reflective processes that could contribute to community wellbeing. The theoretical descriptions are substantiated through examples of action research in Fujuy (Argentina) with former political prisoners and relatives of detainees, or the disappeared, from the time of the last military dictatorship (1976-1983).

Keywords: action research, Argentina, political violence, psychosocial

'It is preferable to fail in a committed attempt to make history as part of a people, than in the pseudo scientific effort to remain at its margin'

Ignacio Martín-Baró, 1998

\section{Psychosocial research with victims and survivors of political violence in Latin America}

A conceptual framework aimed at transformation

The psychological consequences of violence have been widely studied, employing clinical approaches to psycho trauma, and focusing on individual symptoms. While this has been criticised in various English language publications (e.g. Somasundaram, 1998; Strang \& Ager, 2003), there is also a significant body of Spanish language literature on this issue that remains largely ignored in English language publications. One example is the work of social psychologist Martín-Baró (1990), who analysed the war and its effects in El Salvador and conceptualises trauma as a psychosocial phenomenon. He considered conventional models of trauma to be inadequate when confronting the structural and/or direct violence that prevailed in El Salvador. The psychosocial perspective that Martín-Baro developed emphasises that an individual always exists within a specific 
historical context and within a web of social relations. Therefore, in addition to looking for symptoms of individual psycho trauma, we need to explore the impact of violence on social phenomena, such as interpersonal and intergroup relations, as well as the processes of dehumanisation and the naturalisation of violence (Martín-Baró, 1990). Although some studies in Latin America show the utility of an individualistic perspective of trauma, they also confirm the importance of a community focused psychosocial research perspective (Pérez-Sales, Bacic \& Durán, 1998). According to this research, a 'traumatic' event has both a social and a political nature. Therefore, clinical instruments often have limited value in explaining the reactions of people in situations of prolonged repression because they reduce the consequences of the event to symptoms in the individual. This often leads to treatment approaches that are focused on symptomatic treatment of the individual, instead of a community approach. A psychosocial perspective in the sense that is described in this article, takes the dialectical relationship between the individual and his/her social and political world into account (Moreno, 2004; PérezSales, 2006a). In Latin America, such psychosocial perspectives were developed in approaches such as Latin American Community Social Psychology, Social Psychology of War and Liberation Social Psychology. These approaches gained strength in the $1980 \mathrm{~s}$ within the context of the specific problems that affected Latin America at that time: torture, disappearances, human rights violations and the repression of popular movements by military dictatorships. In recent decades, different authors have drawn up a conceptual framework that facilitates work with survivors of political violence and makes it possible to mediate between politics, social experience and collective psychology. This psychosocial framework has made it possible to advance academic knowledge within a wider scope than simply 'exclusive scientific rationality'. It also explicitly aims to contribute to the liberation and emancipation of the subordinated sectors of society (Dobles, 2000; Lira \& Castillo, 1991; MartínBaró, 1990; Montero, 2004; Vásquez, 2000).

Researchers in Latin America who use this specific psychosocial perspective nearly always do so from a position of working with communities to provide active participation and psychosocial support. In this way, research and action are not isolated from each other and research does not necessarily have to precede action, or vice versa. Frequently, both are done simultaneously, and with a state of permanent interaction. The roots of this Latin American research tradition can be found in the writings of John Collier between 1930 and 1945 and Kurt Lewin (Reason \& Bradbury, 2001). These authors tried to explicitly transform the social situation while they researched.

In Latin America, based on the activism and theoretical reflection of authors such as Fals Borda (1959) and Freire (1969, 1979), this led to Participatory Action Research (PAR). PAR is a research methodology that combines research with intervention. The research plays a role in social transformation through active participation of groups and communities. From a theoretical point of view, this implies that the process of collecting knowledge cannot be value free (epistemological neutrality) and it demands a position of commitment towards transformation by the researcher. PAR aims to foster recovery and construction of collective (self) understanding, while stimulating and guiding a praxis of transformation (Lykes \& Coquillón, 2007) and emancipation. It combines methodological rigour with flexibility and 
sensitivity to the demands of a particular setting, the integration of popular knowledge, and the social utility of that knowledge. Initially, PAR used mostly qualitative research approaches, but it is compatible with quantitative approaches (López \& Scandroglio, 2007). To establish validation criteria, PAR does not rely exclusively on statistical criteria nor those based on self attributed, self objectivity in qualitative methodology. It proposes, among other elements, that results should be useful and appreciated by local or community related groups (Fals Borda, 2007).

\section{Methods}

The research project was designed in the Basque Country University (Spain), in collaboration with the Grupo de Acción Comunitaria (Community Action Group), and subsequently discussed and reformulated with Argentinean psychosocial research organisations and officers of governmental human rights programmes. The research focussed on families of the disappeared and survivors of the last military dictatorship in the province of Jujuy (Argentina). Our goals were: a) to examine the psychosocial impact of the last military dictatorship on the relatives of detainees and missing persons; and $\mathrm{b}$ ) to explore the representations of the past, reparation and justice for these people and for the communities where they live. Quantitative tools (questionnaires) were combined with qualitative instruments (in-depth interviews, focus groups and participant observation). Information was collected on: social representations of the dictatorship and its role in collective memory; assessments of the reparation measures from an integral perspective; perceived social support for survivors; awareness and appreciation of human rights organisations; and the impact on social beliefs and identity. The research was not fully based on the principles of PAR. For example: the researchers went to the community, and not vice versa. The difficulties of contacting people were much higher than expected, the geography of the region and the absence of a unified list of missing detainees between public institutions and social organisations hampered opportunities of contacting participants.

Profile and role of researchers in contexts of political violence and/or repression

Sometimes PAR is critised as leading to a dangerous mix of science and activism, and confusing theory with political demands. From the authors' perspective, however, it would be questionable to claim 'impartiality' when facing the suffering caused by violence. When working with victims and survivors of repression, values and political positions are present in the issues studied, in the hypotheses formulated and in the instruments the work is based on. The authors defined the essential requirements of research within the context of political violence as: non-neutrality, commitment, and political involvement with both the study participants and the community. The possibility of creating a link with people, above all, within contexts where distrust generated by violence constitutes a pattern in social relations, is achieved through proximity, presence and continuous contact. Therefore, the profile of a researcher was defined as someone with his/her hands in the clay, capable of getting involved with body, head, hands, eyes, feet and heart. Social involvement creates affective bonds, provokes solidarity and fosters trust, in order to gain access to knowledge of the pains and strategies developed to confront repression, political threat and fear. 
In our research experience in Jujuy, one of the basic requirements that enabled us to work, was to be involved in the activities of relatives and survivors organisations. Sharing moments of everyday life (e.g. a barbecue or other leisure activity) allowed us out to get out of an 'academic corset' and to integrate better into the community. This helped to reduce the social distance between researcher and informant, and 'humanised the relationships, allowing for more intimacy and trust. The authors believed that relationships between outsiders and members from within the community should be dialogic. An external researcher has specialised knowledge, but the members of the community have specific knowledge, often based on their own experiences. Reciprocally linked, both contribute to enriching the research and action (Montero, 1998). Of course, these roles need to be understood in the same way by both the researchers and the collectives they work with, in order to avoid false expectations. Within the context of polarisation in civil society ('if you're with us, you cannot be with them'), a permanent demonstration of transparency and fairness to all was required. This involved systematic collaboration, in both civil actions and the daily work of organisations, by making the research results available and regularly reporting on its progress. Therefore, the authors collaborated in the preparation of reports for submission to the Human Rights State Secretariats, facilitated economic reparation procedures, offered to provide collective memory workshops in schools and run awareness campaigns for organisations.

In many cases, after setting date, time and place, a scheduled interview was cancelled by the person to be interviewed. This happened so often that it appeared to be related to a desire to conceal, or to control what was revealed, and a fear of disclosure (especially in those who experienced guilt and/or shame). In order to conduct a formal interview, sometimes at least five informal meetings with the person or family were needed. It appears this was needed in order to: a) to prepare themselves to speak about what had happened; b) to check that we could be trusted; and c) to identify the level of commitment of the researchers.

Of course, the relationship between researcher and informant cannot be truly on equal level because the opportunities and life chances of each can be very different. However, through coexistence and interaction at work, when it is extended beyond a 'parachute landing' of researchers into the community, impacts on the researcher's identity. This can either extend this social distance or conversely, reduce it.

From our experience, working in Jujuy for two consecutive years, a long term relationship has a strong impact on the perception of many professionals. For example, a researcher may be able to move away from the horror of witnessing inequality and impunity and empathise with the pain. (Garcia del Soto \& Cherfas, 2006), The healthiest position is not to obscure or remove our role as outsiders (i.e., we were not touched personally by the impunity that affected those we worked with and we had the certainty of a return ticket in case of a possible emergency, at any time), but to establish relationships and commitment to the groups where we worked and lived together, (Lykes, 1997). Additionally, denying our specific roles as researchers, human rights observers, activists, and mental health workers could damage the confidence of others. This clarity of our roles helped to avoid building false expectations and/or misunderstandings. Our professional identity also reminded us who we are, where we came 
from and what we are in this place to do. It allows us to project a path for the future.

Research, is at times, part of the intervention. This makes necessary for researchers to acquire the basic skills of psychosocial support interventions. In our research with survivors of political violence, we found cases that required careful handling of the testimony. For example, dealing with the testimony of a person who suffered sexual abuse in a clandestine centre, the researcher should be prepared to provide them with some psychosocial assistance, for a minimum duration of the interview.

\section{Methods used in PAR}

In processes of action research in societies that have faced political violence, triangulation of research methods is important. This means the use of different methods and sources in order to corroborate and explain the outcomes. What happens to survivors cannot be properly understood when removed from the context of what the survivors themselves think about violence, justice and reparation, or the society where they coexist.

A standard closed questionnaire, designed for urban populations accustomed to answering personal questions put to them by a stranger, can be unsuitable in a process of action research in locations where the format for obtaining information, asking and answering, are different (SánchezVidal, 2007). People need to be listened to, to transmit their experience and testimony. Exclusive reliance on questionnaires can seem aggressive to some. They may also feel that their experience is being simplified. Sometimes, the process may remind them of the traumatic events of their past:

'This business of filling in a questionnaire reminds me of what they did to us in prison, they got hold of our profile' ( former Argentinean political prisoner).

Additionally, survivors may be suspicious about how data might be used. On this basis, a sample was defined that incorporated various social actors (survivors and the general population) with different experiences in relation to the object of study and who were asked about the representations of the same stimuli. In order to approach the representations of violence, and the perceptions of the various forms of reparation in the whole society, a community study $(\mathrm{N}=400)$ was carried out through questionnaires including the perceptions of the Jujuy society. They were selected through a random sampling process using proportional allocation by social class, sex, age and town of residence. The questionnaire included: representations of dictatorship, its officers, victims and reparations. It was comprised of both closed questions and open questions that allowed the detection of the social discourses that constructed these perceptions. This design facilitated the integration of quantitative with qualitative methodologies.

For example, we worked with a Likert scale (where $1=$ very poor and $5=$ very well) and asked how well they thought the state had financially compensated survivors. This closed question was accompanied by an open question to explain the reasons for that rating. Quantitative data showed us that nearly $30 \%$ of the respondents thought that the state had 'very badly' or 'fairly badly' financially compensated the survivors. Three subjects categorised the responses to the open ended questions into various categories 1 , including: 'Money does not make good a loss', and 'is a form of silence for the victims"; "That money belongs to the people", and 'they knew what they were and must be made accountable. In this way, we could 
analyse, across socio-demographic variables, which segments of the population held these ideas. These results were then interpreted from the research that others have done on the reparation within the context of political violence in Latin America (Martín Beristain, 2005; Tapattá de Valdez, 2005; among others). The same strategy was used to enquire whether various forms of compensation were possible: exhumations; trials of those responsible; and so on. Closed questions with Likert scales, accompanied by open questions for further qualitative analysis, and coding for statistical treatment were used.

In addition, the technique of Free Word Association (Di Giacomo, 1981) was used in the community study. Subjects were asked to speak the first words that came into their minds spontaneously, as a reaction to the word stimuli: 'victims', 'justice' and 'repair', among others. With data collected for each stimulus (between 700 and 800 words per stimulus), a content analysis was performed, which gave an account of the semantic field associated with these concepts. The initial list of words was ordered in 20 categories. The results suggested that the consensus for the 'victims' stimuli was about pain, suffering, injustice and innocence; 'justice' resulted in corruption, unjust, right and equality; and 'repair' resulted in necessary, and immediate justice.

When dealing with groups directly affected, surveys were combined with other qualitative techniques of data collection. Surveys of families of missing detainees $(n=30)$ and of former political prisoners $(n=22)$ included: open questions; closed and specific scales to measure posttraumatic stress disorder (PTSD) (DSM-IV-TR criteria), grief (Texas Revised Inventory of Grief, TRIG; Faschingbauer, Zisook \& DeVaul, 1987; Spanish adaptation by García-García,
Landa Petralanda, Trigueros Manzona \& Gaminde Inda, 2005); and impact in a belief system (VIVO scale, Pérez-Sales, 2006b; the Corsini scale (Corsini, 2004, Spanish adaptation by Arnoso et al., 2010). This information was supplemented by in-depth interviews with families of missing detainees $(\mathrm{n}=30)$ and former political prisoners $(\mathrm{n}=30)$, focus groups (with the organisations concerned and other relevant social actors) and participant observation at meetings of organisations, truth trials, collective actions (demonstrations, escraches ${ }^{2}$ ) and accompanying of survivors to the offices of the state human rights organisations.

The combination of this set of strategies enabled us to overcome the distrust of the participants towards closed questionnaires, as well as the fear that the research would not gather the totality of their experiences. Furthermore, it made the participants feel that they were not placed in the position of 'victim', which did not reflect their strengths and coping abilities. Combining different methods also enabled us to discover explanations that we would not have been able to identify if we had been using quantitative methodology. For example, the preconceived symptom scales did not list political grief (loss of the political projects of the sixties and seventies militancy). However, many of the participants, especially former political prisoners, made constant reference to pain caused by this loss;

Along with our comrades, we lost the possibility of a more just society, which is what we were struggling for' (ex-political prisoner).

Another outcome of the research was that, for most of those affected, justice was perceived as the highest value reparation method. However, only a minority of the respondents were actively involved in the 
processes of bringing their case to court. Reasons not to go for legal action were: 1) fear of being threatened again; 2) family discussions about the decision; and 3) a general distrust in the legal system. Such information would have been difficult to find through quantitative survey designs. Similar elements were found in Guatemala (Martín Beristain, 1999; Perez-Sales \& Navarro, 2007). It required the combination of qualitative methodological tools to understand their reality in its full dimensions.

\section{Returning the work to the community and possible recommendations for action}

Out of commitment to the participatory dimension of the research, it is necessary to return the results of the work back to the community. This should be done in a language accessible to community, avoiding overly technical language that could silence the reality of the stakeholders again and impede social utility (Wiesenfeld, 2000). The community had a historical and sociocultural development from before the research that will continue after it (Montero, 1998). That is why it is important to reflect collectively, within the community, on the way the link between researcher and community will be maintained once the research process has ended. It is important to transmit the technical knowledge and necessary tools to the community to enable them to use the results constructed together in the research process, in the interests of their own welfare. During the research in Jujuy, the progress was shared and discussed with the concerned organisations in a continuous process. This provided information that may be valuable for both collective action and working with survivors in their pursuit of justice (case identification of survivors in particularly vulnerable situations, families or witnesses who could provide data in the context of justice and that were not detected by the agencies, etc.). In addition, organisations requested the opportunity to develop, along with the results of research, educational materials to work with young people in the schools.

Moreover, what was designed as 'research' in the university, became 'action' when confronted with the reality on the ground. For example, we found how state reparation policies were breaking the inter and intra group solidarity. Selective economic aid, and co-option of some organisations or its members, provoked clashes between groups of survivors and limited their autonomy and capacity for action.

This research enabled us to understand what fears hampered the initiation of a criminal lawsuit by many survivors and relatives of the disappeared (not knowing where to turn, feeling that their experience was not valuable to the process, fear of reprisals, etc.). As a result, the social agents were able to identify the need to build stable communication channels between survivors, concerned organisations and groups of lawyers. Such communication between main actors, could provide detailed information about the implications of criminal proceedings, and facilitate group cohesion that, as an element of psychosocial protection, could face the fear derived from a legal proceeding made alone. After the research, the community had more and better communication about legal processes and possible strategies of protection to deal with impunity and the risks to life. As a result, the criminal charges brought against the oppressors increased.

Also, having more detailed knowledge about the psychosocial impact of violence among survivors enabled the drafting of reports that were presented to government institutions with the objective of supporting the claims 
of organisations in terms of reparation and comprehensive protection.

\section{A framework for PAR with survivors of political} violence

Below are the steps recommended in developing action research processes with survivors of political violence. Table 1 shows:

a) understanding the social environment where it will be developed; b) construction and maintenance of links between external agents and community;

c) methodological design adapted to community needs and the reality of the context in which they fit;

d) definition of spaces and strategies of communication between those involved in detecting risks and opportunities for action; and

e) exploration of strategies for returning research results to the community.

\section{Table 1. Steps for a process of Action Research with survivors of political violence}

1. Familiarisation between researchers and community.

- Visits

- Informal contacts

- Free observation

2. Building trust and commitment: creating and maintaining the link with the community.

- Clarification of objectives and our presence in the community

- Participation in collective actions and solidarity

- Integration into everyday life in the community

3. Redefinition of objectives and methodology adapted to the reality of the context.

- Prioritisation of community needs and collective discussion of the most suitable methodological strategies

- Investigating risks and research opportunities

- Triangulation of methods and sources of information

- Transcultural validation of instruments

- Flexibility, creativity and scientific rigour in the field work

4. Establishment of periodical spaces for discussion of the research process with the community

- Transparency and transmission of knowledge during the whole process;

- Detection of risks and opportunities for intervention and social action.

- Employment of group techniques and dynamics.

5. Systematic return of knowledge and information produced. Making available the tools and technical knowledge for the community to use the results.

- Meetings, community assemblies

- Training in action research techniques and procedures

- Group ownership workshops

- Specific workshops for those involved in psychosocial support/accompaniment for survivors of political violence

- Production of leaflets, short texts and other material for popular education 


\section{Conclusions}

According to our results, it is important to use a broad psychosocial perspective for the study of the impact of political violence in Latin America. The methodological principles of PAR, constitute both a theoretical foundation and a practical basis for research projects aimed at the transformation and empowerment of collectives affected by political repression. The dialectical relationship between the individual, society and the political world makes it necessary to use methods from various disciplines.

In contexts marked by violence, where distrust marks the forms of social relationship, the researcher's involvement and political commitment seem preferable to what we would call pseudoscientific objectivity. Active engagement by the researcher leads to trust and facilitates the attainment of objectives. It should also be recognised that knowledge is constructed through interaction with others. Involvement by the collectives of those affected should be guaranteed in all the phases of the project. Their involvement promotes collective self consciousness and forms part of the dimension of intervention and reparation. It makes it possible to advance social transformation, emancipation and the search for collective welfare.

Finally, the results, should be made accessible to the community. Not only in the final phase of the project, but throughout the process, the collectives involved can thus be enabled to make use of the knowledge that has been constructed collectively.

\section{Acknowledgements}

We would like to thank Dr Pedro Ibarra (Parte Hartuz Research Group, University of the Basque Country) and Dr Pau PérezSales (Grupo de Acción Comunitaria) for their continuous advice and support and Lic Susana Ansaloni for her insightful comments and personal support; as well as Eva Arroyo (H.I.J.O.S.) and the mothers and relatives, ex-political prisoners and human rights lawyers from Jujuy province in Argentina. We thank them for the years shared together, the warmness of our relationships and our collective education. We also thank Bob Curwen for translating this manuscript.

\section{References}

Arnoso, M., Bilbao, M. A., Páez, D., Irarugi, I., Kanyangara, P., Rime, B., Pérez-Sales, P. \& Martín-Beristain, C. (2010). Violencia colectiva y creencias básicas sobre el mundo, los otros y el yo: Impacto y reconstrucción. In: D. Paez, C. M. Beristain, J. L. Gonzalez \& J. De Rivera (Eds.), Superando la violencia colectiva y construyendo cultura de paz. Madrid: Fundamentos.

Bauer, M. \& Gaskell, G. (2000). Qualitative researching with text, image and sound. London: Sage.

Corsini, S. (2004). Everyday Emotional Events and Basic Beliefs. Doctoral thesis. University of Louvain: Louvain la Neuve.

Di Giacomo, J. (1981). Teoría y métodos de análisis de las representaciones sociales. In: S., Ayestaran, (Eds.), Ideología y representación social de la enfermedad mental, III Curso de Verano de la Universidad del País Vasco: Bilbao, España. 397-492.

Dobles, I. (2000). Proceso a la psicología de la liberación: ¿es posible en nuestra América? In: J. J., Vásquez, (Ed.), Psicología social y liberación in América Latina. México: Universidad Autónoma Metropolitana Iztapalapa.

Fals Borda, O. (1959). Acción comunal en una vereda Colombiana. Bogotá: Universidad Nacional de Colombia. 
Psychosocial research and action with survivors of political violence in Latin America: methodological considerations and implications for practice, Intervention 2010, Volume 8, Number 1, Page 3 - 13

Fals Borda, O. (2007). La investigación acción en convergencias disciplinarias. Latin American Studies Association, FORUM. XXXVIII, $17-22$.

Faschingbauer, T., Zisook, S., \& DeVaul, R. (1987). The Texas Revised inventory of grief. In: S. Zisook, (Ed). Biopsychosocial Aspects of Bereavement (pp. 111-124). Washington, D.C.: American Psychiatric Press, Inc.

Freire, P. (1969). La educación como práctica de la libertad. Montevideo: Tierra Nueva.

Freire, P. (1979). Pedagogía del Oprimido. México: Siglo XXI.

García del Soto, A. \& Cherfas, L. (2006). Representaciones de la Acción Humanitaria. Antípoda, 2, 67-90.

García García, J. A., Landa Petralanda, V., Trigueros Manzano, M. C., \& Gaminde Inda, I. (2005). Texas revised inventory of grief: adaptation to Spanish, reliability and validity. Atencion Primaria, 35(7), 353-358.

Lira, E. \& Castillo, I. (1991). Psicología de la amenaza politica y del miedo. Santiago de Chile: Instituto Latinoamericano de Salud Mental y Derechos Humanos.

López, J. S. \& Scandroglio, B. (2007). De la investigación a la intervención: la metodología cualitativa y su integración con la metodología cuantitativa. In A. Blanco \& J. Rodríguez Marin (Eds.), Intervención psicosocial (pp. 557-606). Madrid: Prentice Hall.

Lykes, M. B. (1997). Activist participatory research among the Maya of Guatemala: Constructing meanings from situated knowledge. Fournal of Social Issues, 53(4), 725-746.
Lykes, M. B. \& Coquillón, E. (2007). Participatory and action research and feminisms: Toward transformative praxis. In S. N. Hesse-Biber (Ed.), Handbook of feminist research: Theory and praxis. (pp. 297-326). Thousand Oaks, CA: Sage.

Martín Beristain, C. (1999). Reconstruir el tejido social. Un enfoque crítico de la ayuda humanitaria. Barcelona: Icaria.

Martín Beristain, C. (2005). Reconciliación y democratización en América Latina: un análisis regional. Papel de las políticas de Verdad, Justicia y Reparación. In: IIDH (Ed.), Verdad, justicia y reparación. Desafios para la democraciay la convivencia social. San José: Internacional IDEA.

Martín-Baró, I. (1990). El impacto psicosocial de la Guerra. Guerra y salud mental. In: I. Martín Baró \& J. Samayoa (Eds.,). Psicología social de la Guerra. El Salvador: UCA.

Martín-Baró, I. (1998). Psicología de la liberación. Barcelona: Trotta.

Montero, M. (1998): La Comunidad como objetivo y sujeto de acción social. In: M. González (Ed.), Psicología comunitaria, fundamentos y aplicaciones. Madrid: Síntesis.

Montero, M. (2004). Introducción a la psicología comunitaria. Barcelona: Paidós.

Moreno, F. (2004). Reflexiones sobre el trauma psicológico y la violencia política: de las guerras centroamericanas de los 80 al 11 de marzo de 2004. Clínicay salud: Revista de psicologíaclínica y salud, 15(3), 253-271.

Pérez-Sales, P. (2006a). Trauma, culpa y duelo. Hacia una psicoterapia integradora. Bilbao: Desclée de Brouwer. 
Pérez-Sales, P. (2006b). The VIVO questionnaire. Retrieved 28 January 2010 from http:// www.psicosocial.info.

Pérez-Sales, P., Bacic, R., \& Durán, T. (1998). Muerte y desaparición en la Araucania Chilena. Una aproximación étnica. Santiago de Chile: LOM.

Reason, P. \& Bradbury, H. (2001). Handbook of Action Research: Participative inquiry and practice: xxiii-xxxxi. London: Sage Publications.

SánchezVidal, A. (2007). Manualde Psicología Comunitaria: Un enfoque integrado. Madrid: Pirámide.

Somasundaram, D. (1998). Scarredminds: the psychological impact of war on Sri Lankan tamils. New Delhi: Sage.

Strang, A. B. \& Ager, A. (2003). Psychological Interventions: some key issues facing practitioners. Intervention, 1(3), 2-12.

Tapattá de Valdez, P. (2005). El pasado, un tema central del presente. La búsqueda de verdad y justicia como construcción de una lógica democrática. In: IIDH (Ed.). Verdad, justicia y reparación. Desafíos para la democraciay la convivencia social. San José: Internacional IDEA.
Vásquez, J. (2000). Psicología social y liberación en América Latina. México: Universidad Autónoma Metropolitana Iztapalapa.

Wiesenfeld, E. (2000). Entre la prescripción y la acción: La brecha entre la teoría y la prácticaen las investigaciones cualitativas. Forum Qualitative Social Research, 2. Available at: http:// www.qualitative-research.net/fqs-texte/2-00/ 2-00wiesenfeld-s-pdf.

1 This methodology follows the principles of Classical Content Analysis (CCA) described by Bauer \& Gaskell (2000).

2 Escrache - type of demonstration where a group of activists picket the home or place of work of someone they wish to denounce for some motive before public opinion.

Maitane Arnoso Martinez is a political scientist and psychosocial worker with the Department of Political and Administrative Science University of the Basque Country in Spain and a member of the Community Action Group (www.psicosocial.net) in Spain.

Email:maitane_arnoso@yahoo.es

Francisco José Eiroá Orosa is a psychologist and member of the Community Action Group (wwre.psicosocial.net). 